\title{
SOEP
}

SOEPpapers

on Multidisciplinary Panel Data Research

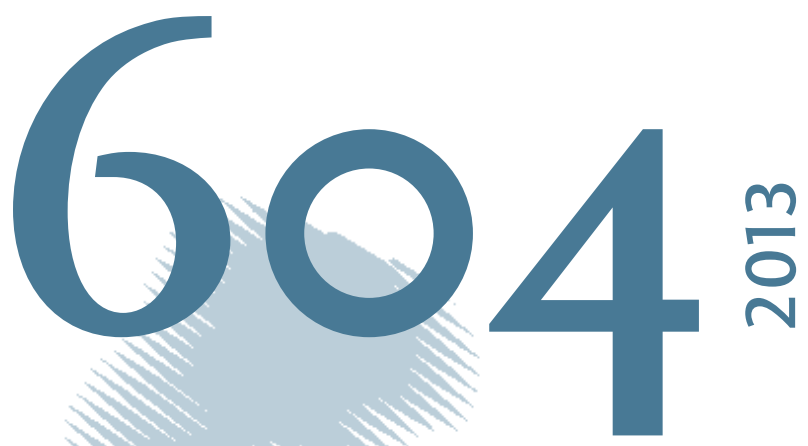

\section{Endogeneity in the relation between poverty, wealth and life satisfaction}




\section{SOEPpapers on Multidisciplinary Panel Data Research}

at DIW Berlin

This series presents research findings based either directly on data from the German SocioEconomic Panel Study (SOEP) or using SOEP data as part of an internationally comparable data set (e.g. CNEF, ECHP, LIS, LWS, CHER/PACO). SOEP is a truly multidisciplinary household panel study covering a wide range of social and behavioral sciences: economics, sociology, psychology, survey methodology, econometrics and applied statistics, educational science, political science, public health, behavioral genetics, demography, geography, and sport science.

The decision to publish a submission in SOEPpapers is made by a board of editors chosen by the DIW Berlin to represent the wide range of disciplines covered by SOEP. There is no external referee process and papers are either accepted or rejected without revision. Papers appear in this series as works in progress and may also appear elsewhere. They often represent preliminary studies and are circulated to encourage discussion. Citation of such a paper should account for its provisional character. A revised version may be requested from the author directly.

Any opinions expressed in this series are those of the author(s) and not those of DIW Berlin. Research disseminated by DIW Berlin may include views on public policy issues, but the institute itself takes no institutional policy positions.

The SOEPpapers are available at

http://www.diw.de/soeppapers

\section{Editors:}

Jürgen Schupp (Sociology)

Gert G. Wagner (Social Sciences, Vice Dean DIW Graduate Center)

Conchita D'Ambrosio (Public Economics)

Denis Gerstorf (Psychology, DIW Research Director)

Elke Holst (Gender Studies, DIW Research Director)

Frauke Kreuter (Survey Methodology, DIW Research Professor)

Martin Kroh (Political Science and Survey Methodology)

Frieder R. Lang (Psychology, DIW Research Professor)

Henning Lohmann (Sociology, DIW Research Professor)

Jörg-Peter Schräpler (Survey Methodology, DIW Research Professor)

Thomas Siedler (Empirical Economics)

C. Katharina Spieß (Empirical Economics and Educational Science)

ISSN: 1864-6689 (online)

German Socio-Economic Panel Study (SOEP)

DIW Berlin

Mohrenstrasse 58

10117 Berlin, Germany

Contact: Uta Rahmann | soeppapers@diw.de 


\title{
Endogeneity in the relation between poverty, wealth and life satisfaction
}

\author{
André Hajek ${ }^{1}$
}

Lüneburg

November 2013

\begin{abstract}
${ }^{1}$ This publication is a modified extract of my dissertation "Der Einfluss von Armut und Reichtum auf die Lebenszufriedenheit. Eine empirische Analyse mit dem SOEP unter besonderer Berücksichtigung des Capability Approach" ("The Influence of Poverty and Wealth on Satisfaction of Life. An empirical analysis with SOEP data, paying particular attention to Capability Approach") published by Herbert Utz.
\end{abstract}

E-Mail: andrehajek@alice-dsl.net

Gratefully and sincerely I would like to thank my supervisor - Prof. Dr. Hans-Rüdiger Pfister - for his guidance and support during my dissertation. His continuous encouragement and insightful comments helped a lot. 
Endogeneity in the relation between poverty, wealth and life satisfaction

André Hajek

Abstract

This paper concentrates on the complex interplay between poverty, wealth and life satisfaction. Main areas of life are quantified in a multidimensional approach of poverty and wealth: Individual income, current health, occupational autonomy or employment status and life satisfaction. The analyzed data was taken from the German Socio Economic Panel Study (SOEP) at the German Institute for Economic Research (DIW Berlin), Berlin. A period from 1998-2009 is examined. This study has two main goals: (1) To contribute to the interconnection between poverty, wealth and life satisfaction. (2) The endogeneity research regarding life satisfaction should be expanded. Reduced form vectorautoregressions (with first differences) were used to answer the questions. Therefore, granger-causality can be assumed. Major findings include: an initial rise in life satisfaction can improve income and health, but not job autonomy. However, even the probability of returning from unemployment to employment can increase. Gender-specific differences are discussed.

JEL: I19, I31, I32, J64

Keywords: life satisfaction, unemployment, SOEP, vector autoregressions, endogeneity, income, health, occupational autonomy

Zusammenfassung

Der Fokus dieser Arbeit liegt auf der komplexen Wechselwirkung zwischen Armut, Reichtum und Lebenszufriedenheit. Die Konzentration gilt zentralen Bereichen des Lebens: Individuelles Einkommen, subjektiver Gesundheitszustand, berufliche Autonomie bzw. Erwerbstätigkeit sowie der angesprochenen Lebenszufriedenheit. Die Daten dieser Publikation beruhen auf Zahlen des Soziooekonomischen Panels (SOEP) am Deutschen Institut für Wirtschaftsforschung (DIW Berlin), Berlin. Es wird ein Zeitraum von 1998-2009 betrachtet. Dadurch wird überwiegend ein Beitrag zur Endogenitätsfrage geleistet und das verzweigte Zusammenspiel dieser Größen abgebildet. Methodisch wird dazu auf Reduced Form Vektorautoregressionen (mit First Differences) zurückgegriffen. Granger-Kausalität kann angenommen werden. Zentrale Ergebnisse: Ein anfänglicher Anstieg der Zufriedenheit erhöht das individuelle Einkommen sowie den Gesundheitszustand, aber nicht die berufliche Autonomie. Hingegen kann sich die Wahrscheinlichkeit erhöhen, dass man von einer Arbeitslosigkeit zurück in die Vollerwerbstätigkeit gelangt. Diskrepanzen zwischen den Geschlechtern werden diskutiert.

JEL: I19, I31, I32, J64

Schlagwörter: Lebenszufriedenheit, Arbeitslosigkeit, SOEP, Vector-Autoregressionen, Endogenität, Einkommen, Gesundheit, berufliche Autonomie 


\section{Content}

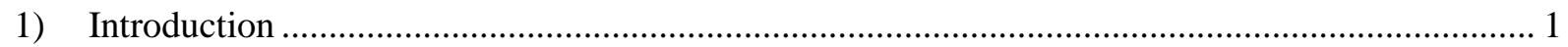

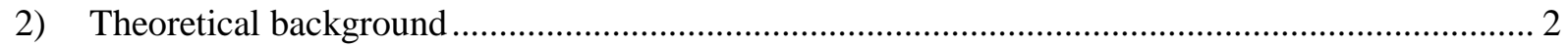

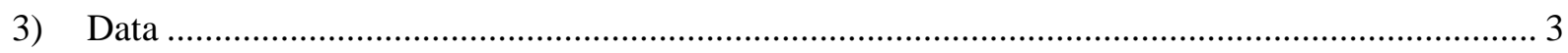

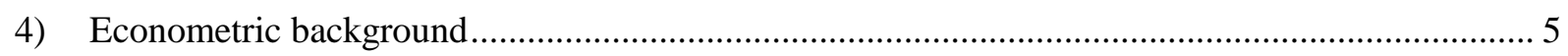

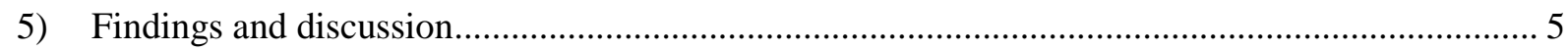

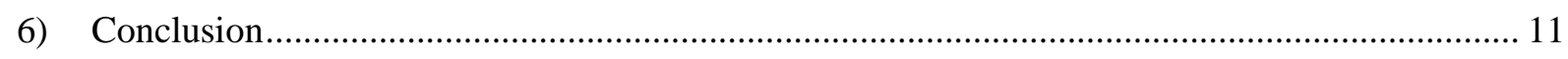

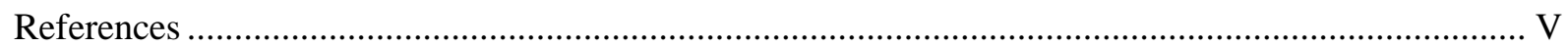




\section{Contents of Tables}

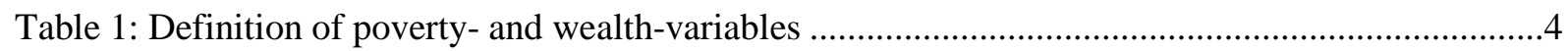

Table 2: Descriptive Statistics of dependent variable and control variables $(n=249.783)$......................

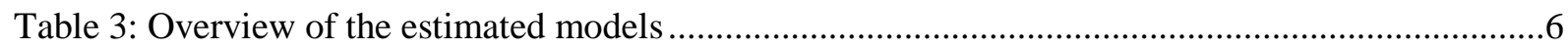

Table 4: Two-Lag Vector Autoregressions for poor, middle class and wealth (OLS- and Ordered-Probit-Regressions, Model Ia) . .9

Table 5: Two-Lag Vector Autoregressions for poor, middle class and wealth - divided by sex (OLS- and Ordered-Probit-Regressions, Model Ia) .10 


\section{1) Introduction}

Measuring life satisfaction becomes more and more popular. This measure provides information about the self-assessed evaluation of one's life. Political discussions can benefit from satisfaction research, also scientific disciplines like economy or psychology benefit from investigating well-being.

Many authors study satisfaction in a rigid way. Satisfaction is usually treated as dependent variable. However, life satisfaction of individuals depends on many different aspects and complex relationships between different variables. Therefore, one cannot be sure about the causality in the relationship between satisfaction and major domains of life, e.g. health, occupation or income. However, these constructs are of high scientific and public relevance. For instance, lots of popular science books try to emphasize the impact of a good mood on life satisfaction. In science, Becchetti, Pelloni and Rossetti (2008, p. 356) indicate that endogeneity is a major problem in life satisfaction research. Beyond that, it can refute the assumption that life satisfaction has only a short term impact.

Therefore, it appears to be necessary to have a closer look at endogeneity. One cause for endogeneity is simultaneity. Simultaneity is characterized by the dependence between regressor and regressand. Consequently, one cannot talk about one regressand. Take for example the relation between life satisfaction (regressand) and health (regressor): The regressand is not only influenced by the regressor, the regressand also affects the regressor.

Studying this complex interplay, this publication concentrates on major life domains (income, health and the occupational autonomy/unemployment) and their relationship with life satisfaction. Thus, the aim of this study is to determine the diverse interplay between life satisfaction and the above mentioned variables within the scope of poverty and wealth research in Germany. Moreover, the present study contributes to answer the question of causality between the investigated variables.

In the context of poverty and wealth, the above named question is of importance for several reasons. Poverty on its own implies a need for action. In addition to that, a drop down in satisfaction could lead to unemployment. Again, unemployment can reduce satisfaction. Therefore, insights in the complex relationship are relevant for political discussion as well. This is also true in case of wealth.

Primarily on the basis of vector autoregressions the interplay between changes in life satisfaction and changes in the described variables is analyzed. Using German Socio-Economic Panel (SOEP) from the time period 1998-2009, this interplay is investigated.

This article has the following structure: Chapter 2 gives an overview of the literature in this research area. The following chapter defines the database in general and the variables used. The fourth chapter provides an outline regarding the estimation method applied in this paper. Findings are presented and discussed in chapter five. In the last chapter, the results are summarized and an outlook is given. 


\section{2) Theoretical background}

The key results in this research area are summarized below. Graham, Eggers and Sukhtankar (2004) addressed the topic of reverse causality between life satisfaction and (a) health, (b) income and (c) labour status. For this purpose they used data of RLMS (years 1995 and 2000). Life satisfaction was measured using a verbalized 5-point rating scale ${ }^{2}$. They estimated happiness with a number of usual regressors by applying ordered logit regressions (years 1995 and 2000). Subsequently, Graham et al. (2004) solved the problem of self-selection by using ordered logit panel regressions (fixed effects were eliminated by first differences). Afterwards, the residual happiness (year 1995) was applied to estimate income, health and labour status (year 2000). They showed that people who had a higher satisfaction in the year 1995, earned more money and had a better health in the year 2000, though the residual happiness did not influence the probability of being employed.

By using longitudinal data (BHPS), Gardner and Oswald (2007) investigated lottery players without a win, with a small $(<1.000$ pounds) and a medium-sized $(<120.000$ pounds $)$ win. The dependent variable was mental health (GHQ-12). The independent variable can be interpreted as a positive exogenous income shock. They could demonstrate that a medium-sized win boosts the mental health. One has to keep in mind that the income shocks for reasons of sample sizes are relatively small which raise concern about the accuracy of results.

In recent years, the increased use of autoregressive methods can be observed (e. g. Binder \& Coad, 2010; Binder \& Ward, 2011; Bottan \& Truglia, 2011). The aim is to better describe the complex interaction of life satisfaction and its regressors. For example, Bottan and Truglia (2011) utilize in this context dynamic panel data models (like Arellano-Bond- and Anderson-Hsiao-estimators) with fixed effects. These estimators (Structural Vector Autoregressions (VARs)) strongly depend on the instruments. If the instruments are weak, the results are unreliable. This has led to a new approach in satisfaction research applied by Binder and Coad (2010). They examined endogeneity in the research field of mental well-being (GHQ-12) with BHPS-data. The authors proposed that in reality interdependencies between mental well-being and other exogenous variables exist. Therefore, they do not assume any kind of causal relationship, but rather consider the coevolution of well-being, health, family status, labour status and income. For that purpose, Binder and Coad (2010) used reduced form VARs (Stock \& Watson, 2001).

In contrast to the structural VARs thoughts about causality as well as the problems of weak instruments are omitted. Hence, one cannot deduce policy recommendations. However, the identified relations may be seen as evidence of potential causalities. Similarly, the aim is to get "a more complete, comprehensive view of the phenomenon" (Binder \& Coad, 2011, p. 331).

\footnotetext{
${ }^{2}$ Options: "not at all satisfied", "less than satisfied", "both yes and no", "rather satisfied" and "fully satisfied". Health was measured by an index of three equally weighted items (in detail: Graham et al., 2004, p. 323).
} 
By utilizing reduced form VARs, they found out: When mental well-being rose in the past wave, the probability of an increase in mental well-being in the present wave drops down. This can be seen as an adaptation-effect. Further, recent improvements in mental well-being are significantly related to following enhancements in logarithmized gross income and health. In comparison, improvements in income are associated with subsequent decreases in well-being. However, progresses in health have no effects on prospective mental well-being. Therefore, the mental well-being can have long-lasting effects: Positive changes in mental well-being lead to better health. These progresses improve the employment-status, which in turn leads to an income growth.

\section{3) Data}

The present research uses SOEP data. It is a representative annually longitudinal study of private households since 1984. It is located at the German Institute for Economic Research (DIW Berlin). Approximately 11.000 households (about 20.000 individuals) take part every year. Some of the major topics are subjective well-being, income, health, employment, time use or social exclusion (for further details see: Wagner, Frick \& Schupp, 2007).

Every year life satisfaction is operationalized with the question "How satisfied are you with your life, all things considered?". People respond to this item on an 11-point rating scale (ranging from 0 "completely dissatisfied" to 10 "completely dissatisfied"). According to Schimmack (2009) and other authors this scale is reliable and valid.

The other three endogenous variables are assessed as follows: (1) Subjective health is measured on a 5-point scale (bad; poor; satisfactory; good; very good). (2) The scale "Autonomy in occupational activity" (1="low autonomy" to 5="high autonomy", cf. Hoffmeyer-Zlotnik \& Geis, 2003, p. 133) is applied to calculate the job autonomy. To check the robustness of the results, also the SIOPS, ISEI, MPS and EGP-classifications were utilized to measure job autonomy. (3) To quantify the (net) individual income, it is asked annually:

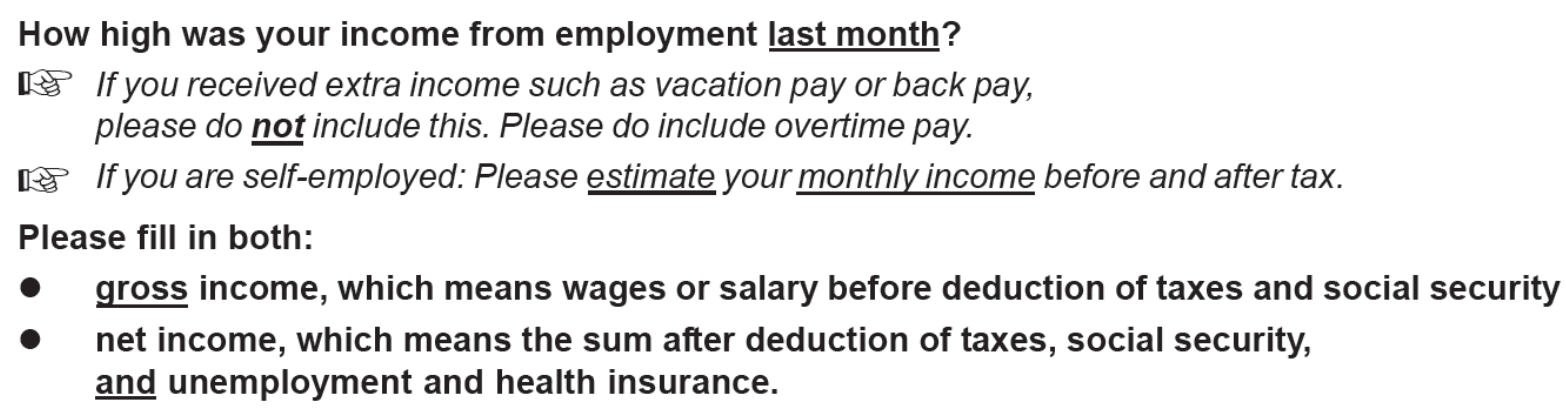

[1 If you are self-employed: Please estimate your monthly income before and after tax.

Please fill in both:

- gross income, which means wages or salary before deduction of taxes and social security

- net income, which means the sum after deduction of taxes, social security, and unemployment and health insurance.

My income was:

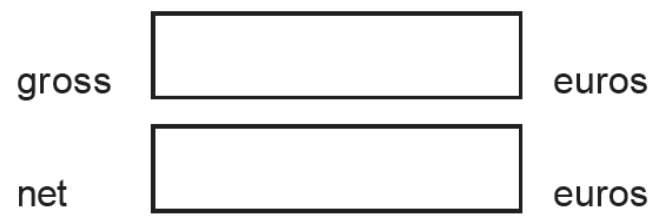


The following variables were used in the first models as control variables: personal situation ( $0=$ not married; divorced; separated from my spouse/partner; spouse/partner died; spouse live abroad; $1=$ married, living together) and year effects.

Table 1 gives an overview of the definition of poverty as well as wealth-variables and table 2 summarizes the main descriptive statistics.

Table 1: Definition of poverty- and wealth-variables

\begin{tabular}{|c|c|c|c|c|}
\hline & $\begin{array}{l}\text { Definition of } \\
\text { wealth }\end{array}$ & $\begin{array}{l}\text { Definition of non- } \\
\text { wealth }\end{array}$ & $\begin{array}{l}\text { Definition of } \\
\text { poverty }\end{array}$ & $\begin{array}{l}\text { Definition of non- } \\
\text { poverty }\end{array}$ \\
\hline Individual income & $\begin{array}{l}\geq 300 \% \text { median } \\
\text { of individual net } \\
\text { income }\end{array}$ & $\begin{array}{l}<300 \% \text { median of } \\
\text { individual net } \\
\text { income }\end{array}$ & $\begin{array}{l}\leq 60 \% \text { median of } \\
\text { individual net } \\
\text { income }\end{array}$ & $\begin{array}{l}>60 \% \text { median of } \\
\text { individual net } \\
\text { income }\end{array}$ \\
\hline Household income & $\begin{array}{l}\geq 200 \% \text { median } \\
\text { of household net } \\
\text { income }\end{array}$ & $\begin{array}{l}<200 \% \text { median of } \\
\text { household net } \\
\text { income }\end{array}$ & $\begin{array}{l}\leq 60 \% \text { median of } \\
\text { household net } \\
\text { income }\end{array}$ & $\begin{array}{l}>60 \% \text { median of } \\
\text { household net } \\
\text { income }\end{array}$ \\
\hline $\begin{array}{l}\text { Subjective current } \\
\text { health }\end{array}$ & $\begin{array}{l}\text { „Very good“ } \\
\text { subjective current } \\
\text { health }\end{array}$ & $\begin{array}{ll}\text { „Bad“ to "good“ } \\
\text { subjective } \\
\text { health }\end{array}$ & $\begin{array}{l}\text { "Bad" subjective } \\
\text { current health }\end{array}$ & $\begin{array}{l}\text { "Poor" to "very } \\
\text { good" subjective } \\
\text { current health }\end{array}$ \\
\hline $\begin{array}{l}\text { Autonomy in } \\
\text { occupational activity }\end{array}$ & Value $=5$ & Value $<5$ & Value $=1$ & Value $>1$ \\
\hline SIOPS (first definition) & Values $\geq 70$ & Values $<70$ & Values $\leq 25$ & Values $>25$ \\
\hline $\begin{array}{ll}\text { SIOPS } & \text { (second } \\
\text { definition) }\end{array}$ & & & Values $\leq 20$ & Values $>20$ \\
\hline ISEI (first definition) & Values $\geq 70$ & Values $<70$ & Values $\leq 25$ & Values $>25$ \\
\hline ISEI (second definition) & & & Values $\leq 20$ & Values $>20$ \\
\hline MPS (first definition) & Values $\geq 100$ & Values $<100$ & Values $\leq 35$ & Values $>35$ \\
\hline MPS (second definition) & Values $\geq 120$ & Values $<120$ & Values $\leq 32$ & Values $>32$ \\
\hline EGP-classification & "high service" & Not "high service" & $\begin{array}{l}\text { "semi-unskilled } \\
\text { manual" }\end{array}$ & $\begin{array}{l}\text { Not "semi- } \\
\text { unskilled manual" }\end{array}$ \\
\hline
\end{tabular}

Comments: The middle class is a result of individuals, who are not classified as poor or rich. Furthermore, other thresholds were used for income (200\% median for wealth and $40 \%$ median for poverty). However, the results do not differ substantially.

Table 2: Descriptive Statistics of dependent variable and control variables $(\mathrm{n}=249.783)$

\begin{tabular}{|c|c|c|c|c|}
\hline & Mean & SD & Min & Max \\
\hline life satisfaction & 6,98 & 1,78 & $\overline{0}$ & 10 \\
\hline income $(0=$ poverty; $1=$ middle class; $2=$ wealth $)$ & 0,87 & 0,60 & 0 & 2 \\
\hline current health $(0=$ poverty; $1=$ middle class; $2=$ wealth $)$ & 1,06 & 0,36 & 0 & 2 \\
\hline autonomy $(0=$ poverty; $1=$ middle class; $2=$ wealth $)$ & 0,9 & 0,43 & 0 & 2 \\
\hline employment status $(0=$ unemployed, $1=$ full-time employed $)$ & 0,86 & 0,35 & 0 & 1 \\
\hline employment status $(0=$ non-working, $1=$ full-time employed $)$ & 0,58 & 0,49 & 0 & 1 \\
\hline married (1=yes) & 0,6 & 0,49 & 0 & 1 \\
\hline
\end{tabular}




\section{4) Econometric background}

Considering endogeneity, a vector autoregressive model is applied (cf. Binder \& Coad, 2010, 2011). Thereby potential direct and reverse causalities can be taken into account. Life satisfaction is regarded as a metric variable. To control for unobserved heterogeneity, the first differences approach is applied. Moreover, the dynamic of life satisfaction is considered by using time lags (equation 4-1).

$$
A_{i t}=\pi_{0}+\sum_{\tau=t-s}^{t-1} \pi_{\tau} A_{i \tau}+\beta X_{i t-1}+\varepsilon_{i t}
$$

The vector A contains the endogenous variables: life satisfaction, income, subjective current health and job autonomy or labour status. The number of lags is a result of $\tau=\mathrm{t}$-s.

Coefficients are $\pi_{\tau}$. Vector X includes the control variables (with coefficients $\beta$ ) and the error term is denoted as $\varepsilon$. The selection of endogenous variables (income, health and (a) occupational autonomy or (b) labour status) in this poverty- and wealth-context is based on theoretical thoughts. ${ }^{3}$

Each of the four endogenous variables is treated as dependent variable once. Hence, in the first case the change $e^{4}$ of life satisfaction is the regressand and the lagged values of life satisfaction and the other endogenous variables (besides the control variables) are treated as regressors. In the second case, the income variable is the dependent variable and the lagged values of income and the other endogenous variables are (besides the control variables) regarded as independent variables et cetera.

This approach is close to granger-causality. According to granger-causality, variable $\mathrm{X}$ "granger causes" $\mathrm{Y}$ when the past values of $\mathrm{X}$ are useful in forecasting $\mathrm{Y}$ and beyond the information contained in past values of $\mathrm{Y}$ alone. This is not equivalent to causality in a common sense and this should be taken into account, when the term effect (interchangeable: influence or impact) is used in this publication (chapter 5).

\section{5) Findings and discussion}

Life satisfaction is estimated by OLS regressions, whereas the other variables are estimated by Ordered-Probit regressions. ${ }^{5}$ Table 3 gives an overview of the models. Furthermore, all models were assessed for the whole population and divided by sex. ${ }^{6}$

\footnotetext{
${ }^{3}$ Therefore, an increased income can gain satisfaction. The raised satisfaction can, in turn, increment income (Clark et al., 2008).

Likewise, the causality between life satisfaction and health (e. g. Easterlin, 2003, p. 11177) as well as life satisfaction and unemployment (Kassenböhmer \& Haisken-DeNew, 2009) seems to be unclear.

${ }^{4}$ Hence, the fixed effects are eliminated by using the first differences approach.

${ }^{5}$ Cf. to the number of lags: Stock \& Watson (2007, p. 640).

${ }^{6}$ By the way: Even if the variables are not classified into poverty, middle class and wealth, the results are almost the same.

Detailed regression results are available from the author on request.
} 
Table 3: Overview of the estimated models

\begin{tabular}{|c|c|c|c|}
\hline Model & $\begin{array}{l}\text { Number } \\
\text { of lags }\end{array}$ & Control variables & Major variables \\
\hline Ia & 2 & $\begin{array}{l}\text { Standard } \\
\text { variables }\end{array}$ & $\begin{array}{l}\text { Life satisfaction (0-10) } \\
\text { Subjective health (Poverty, Middle class and Wealth) }\end{array}$ \\
\hline $\mathrm{Ib}$ & 3 & & $\begin{array}{l}\text { Individual net income (Poverty, Middle class and Wealth) } \\
\text { Occupational autonomy (Poverty, Middle class and Wealth) }\end{array}$ \\
\hline IIa & 2 & $\begin{array}{ll}\text { Standard } & \text { control } \\
\text { variables } & \end{array}$ & $\begin{array}{l}\text { Life satisfaction (0-10) } \\
\text { Subjective health (Poverty, Middle class and Wealth) } \\
\text { Individual net income (Poverty, Middle class and Wealth) } \\
\text { Employment status ( } 0=\text { non-working; } 1 \text { = full-time employed) }\end{array}$ \\
\hline $\mathrm{IIb}$ & 3 & $\begin{array}{l}\text { Standard } \\
\text { variables }\end{array}$ & $\begin{array}{l}\text { Life satisfaction (0-10) } \\
\text { Subjective health (Poverty, Middle class and Wealth) } \\
\text { Individual net income (Poverty, Middle class and Wealth) } \\
\text { Employment status ( } 0 \text { = non-working; } 1 \text { = full-time employed) }\end{array}$ \\
\hline IIIa & 2 & $\begin{array}{l}\text { Extended control of } \\
\text { family situation }\end{array}$ & $\begin{array}{l}\text { Life satisfaction (0-10) } \\
\text { Subjective health (Poverty, Middle class and Wealth) } \\
\text { Individual net income (Poverty, Middle class and Wealth) } \\
\text { Employment status ( } 0=\text { non-working; } 1 \text { = full-time employed) }\end{array}$ \\
\hline IIIIb & 3 & $\begin{array}{l}\text { Extended control of } \\
\text { family situation }\end{array}$ & $\begin{array}{l}\text { Life satisfaction (0-10) } \\
\text { Subjective health (Poverty, Middle class and Wealth) } \\
\text { Individual net income (Poverty, Middle class and Wealth) } \\
\text { Employment status ( } 0 \text { = non-working; } 1 \text { = full-time employed) }\end{array}$ \\
\hline IVa & 2 & $\begin{array}{l}\text { Extended control of } \\
\text { family situation }\end{array}$ & $\begin{array}{l}\text { Life satisfaction (0-10) } \\
\text { Subjective health (Poverty, Middle class and Wealth) } \\
\text { Individual net income (Poverty, Middle class and Wealth) } \\
\text { Employment status ( } 0=\text { unemployed, } 1=\text { full-time employed) }\end{array}$ \\
\hline $\mathrm{IVb}$ & 3 & $\begin{array}{l}\text { Extended control of } \\
\text { family situation }\end{array}$ & $\begin{array}{l}\text { Life satisfaction (0-10) } \\
\text { Subjective health (Poverty, Middle class and Wealth) } \\
\text { Individual net income (Poverty, Middle class and Wealth) } \\
\text { Employment status ( } 0=\text { unemployed, } 1=\text { full-time employed) }\end{array}$ \\
\hline
\end{tabular}

Comments: Occupational autonomy is based on the scale "Autonomy in occupational activity". The category "Apprentice, intern, unpaid trainee" $(=0)$ was excluded for calculations. Source: author's illustration.

Based on model Ia it can be said that a gain (loss) in health increases (decreases, p>.10) life satisfaction (first lag). Further, an initial rise in satisfaction enhances the probability of being in a higher category of income (first lag and second lag), professional autonomy (second lag) and current health (first lag and second lag) (see table 4; separated by sex: table 5).

Model Ib underpins most of these findings. It needs to be mentioned that the impact of life satisfaction on health is also significant in the third lag. However, the influence of an increase in satisfaction is not significant for changes in job autonomy. 
Divided into subgroups (men and women, model Ia): The effect of an increased (decreased) health on life satisfaction (first lag) is only significant for men. Otherwise, gains in satisfaction improve the probability of being in a higher category of occupational autonomy (second lag, p>.10) and health (first lag and second lag). For men, an enhancement in satisfaction affects only the probability of being in a higher category of income (first lag and second lag) (for an overview see Table 5).

On the level of sub-groups the results of model Ib generally support the previous findings. In contrast to model Ia a rise in women's life satisfaction does not affect the probability of being in a higher category of job autonomy significantly. Moreover, the positive influence of satisfaction on professional autonomy for women is also observed, when the occupational autonomy is measured by the SIOPS or the EGP-scale. ${ }^{7}$ On the other hand, none of the alternative scales for measuring occupational autonomy (EGP-, ISEI-, MPS- as well as SIOPS-classification) affect satisfaction significantly.

Regarding the robustness of the findings it should be noted, some points are worth noting: Model IIa and IIb indicate that a return from non-working to full-time employment (first lag, $p<.01$ ) enhances life satisfaction overall and - divided by sex - only for men.

Possibly, life satisfaction is also influenced by changes in personal circumstances (e. g. birth of a child). These circumstances might affect changes from full-time employment to non-working. An extended control of the personal situation seems to be helpful. Hence, some more control variables were introduced (model IIIa and IIIb): married; moved in with my partner; son or daughter left the household; had a child; separated from my spouse/partner; got divorced; spouse/partner died; other.

These models indicate that the positive impact of an employment on satisfaction is strengthened (overall and especially for men). Missing effects of an increase in satisfaction on employment status might be explained by the fact that non-working is a free decision. One can assume that unemployment is often - contrary to non-working - an involuntary decision (cf. Hajek, 2013, chapter 5). Therefore, the employment-variable could be generated in another way: $0=$ unemployed; $1=$ full-time employed (model IVa and IVb).

Results of the models IVa and IVb demonstrate that a return from unemployment to full-time employment enhances life satisfaction (first lag with $p<.01$ and second lag with $p<.05^{8}$ ). In the other direction this influence is also significant (first lag and second lag). Separated by sex (model IVa and IVb) it is evident that a change from unemployment to full-time employment increases only men's satisfaction (first lag and second lag). In the reverse direction (impact of life satisfaction on employment-status) different results are obtained: In almost every model this effect is significant (first lag and second lag). Hence, this impact can be regarded as robust.

\footnotetext{
${ }^{7}$ However, this relationship is not significant when ISEI- or MPS-scale is used.

${ }^{8}$ Exception: $\mathrm{p}<.10$ for 2-Lag-model.
} 
These results imply a middle- to long-term influence of life satisfaction. I showed that a gain in satisfaction can enhance the current health and that this effect is robust. This can improve the probability that one returns from unemployment to full-time employment. The job can enlarge individual income as well. Thus, life satisfaction can have a sustainable impact in a variety of ways. 
Table 4: Two-Lag Vector Autoregressions for poor, middle class and wealth (OLS- and Ordered-Probit-Regressions, Model Ia)

\begin{tabular}{|c|c|c|c|c|c|}
\hline & & $\Delta$ Life satisfaction & $\begin{array}{c}\Delta \text { Individual income } \\
\text { (Poverty, Middle class and Wealth) }\end{array}$ & $\begin{array}{c}\Delta \text { Professional autonomy } \\
\text { (Poverty, Middle class and Wealth) }\end{array}$ & $\begin{array}{c}\Delta \text { Subjective health } \\
\text { (Poverty, Middle class and Wealth) }\end{array}$ \\
\hline \multirow{7}{*}{$\Delta \mathrm{t}-1$} & Life satisfaction & $-0.561 * *(0.00502)$ & $0.0153 * *(0.00540)$ & $0.00555(0.00663)$ & $0.0149 * *(0.00551)$ \\
\hline & Individual income (poverty) & $-0.0120(0.0261)$ & $1.866 * *(0.0300)$ & $-0.124 * *(0.0402)$ & $-0.00514(0.0333)$ \\
\hline & Individual income (wealth) & $0.0213(0.0230)$ & $-2.008^{* *}(0.0308)$ & $0.108 *(0.0421)$ & $-0.0259(0.0353)$ \\
\hline & Occupational autonomy (poverty) & $0.00849(0.0287)$ & $-0.0387(0.0336)$ & $2.499 * *(0.0342)$ & $0.0219(0.0358)$ \\
\hline & Occupational autonomy (wealth) & $0.0328(0.0351)$ & $0.182^{* *}(0.0562)$ & $-2.346^{* *}(0.0438)$ & $-0.0861+(0.0490)$ \\
\hline & Subjective health (poverty) & $-0.119+(0.0617)$ & $0.0814(0.0674)$ & $0.0821(0.0784)$ & $2.254 * *(0.0504)$ \\
\hline & Subjective health (wealth) & $0.0585^{* *}(0.0179)$ & $-0.0304(0.0264)$ & $-0.0531+(0.0298)$ & $-2.274 * *(0.0237)$ \\
\hline \multirow{10}{*}{$\Delta \mathrm{t}-2$} & Life satisfaction & $-0.265 * *(0.00455)$ & $0.0128 *(0.00559)$ & $0.0135 *(0.00657)$ & $0.0126 *(0.00527)$ \\
\hline & Individual income (poverty) & $-0.00156(0.0258)$ & $0.886^{* *}(0.0302)$ & $-0.0518(0.0375)$ & $-0.00875(0.0332)$ \\
\hline & Individual income (wealth) & $-0.0158(0.0234)$ & $-0.997 * *(0.0316)$ & $0.0824 *(0.0404)$ & $-0.0123(0.0343)$ \\
\hline & Occupational autonomy (poverty) & $0.0232(0.0263)$ & $-0.00336(0.0288)$ & $1.229 * *(0.0305)$ & $0.0375(0.0343)$ \\
\hline & Occupational autonomy (wealth) & $0.0139(0.0359)$ & $0.161 * *(0.0530)$ & $-1.104 * *(0.0456)$ & $-0.000790(0.0491)$ \\
\hline & Subjective health (poverty) & $-0.0562(0.0657)$ & $0.0114(0.0718)$ & $0.0279(0.0778)$ & $1.104 * *(0.0495)$ \\
\hline & Subjective health (wealth) & $0.0200(0.0169)$ & $-0.0260(0.0239)$ & $-0.0615^{*}(0.0292)$ & $-1.103^{* *}(0.0197)$ \\
\hline & Year effects & Yes & Yes & Yes & Yes \\
\hline & (Pseudo-)R $\mathrm{R}^{2}$ & 0.252 & 0.207 & 0.277 & 0.266 \\
\hline & Number of observations & 65.958 & 62.663 & 62.253 & 65.962 \\
\hline
\end{tabular}

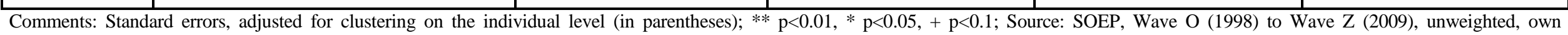
calculations. 
Table 5: Two-Lag Vector Autoregressions for poor, middle class and wealth - divided by sex (OLS- and Ordered-Probit-Regressions, Model Ia)

\begin{tabular}{|c|c|c|c|c|c|c|c|c|c|}
\hline & & \multicolumn{2}{|c|}{$\Delta$ Life satisfaction } & \multicolumn{2}{|c|}{$\begin{array}{c}\Delta \text { Individual income } \\
\text { (Poverty, Middle class and Wealth) }\end{array}$} & \multicolumn{2}{|c|}{$\begin{array}{c}\Delta \text { Occupational autonomy } \\
\text { (Poverty, Middle class and Wealth) }\end{array}$} & \multicolumn{2}{|c|}{$\begin{array}{c}\Delta \text { Subjective health } \\
\text { (Poverty, Middle class and Wealth) }\end{array}$} \\
\hline & & Mann & Frau & Mann & Frau & Mann & Frau & Mann & Frau \\
\hline \multirow{7}{*}{$\Delta \mathrm{t}-1$} & Life satisfaction & $-0.567 * *(0.00679)$ & $-0.555 * *(0.00744)$ & $0.0246 * *(0.00759)$ & $0.00540(0.00766)$ & $0.00309(0.00890)$ & $0.00959(0.0100)$ & $0.0115(0.00760)$ & $0.0186 *(0.00799)$ \\
\hline & Individual income (poverty) & $-0.0163(0.0474)$ & $-0.0115(0.0313)$ & $1.867 * *(0.0541)$ & $1.882 * *(0.0373)$ & $-0.113+(0.0673)$ & $-0.137 *(0.0546)$ & $0.0360(0.0649)$ & $-0.0221(0.0384)$ \\
\hline & Individual income (wealth) & $0.00947(0.0256)$ & $0.0754(0.0526)$ & $-2.005 * *(0.0357)$ & $-2.010 * *(0.0687)$ & $0.114 * *(0.0432)$ & $0.0552(0.106)$ & $-0.0361(0.0396)$ & $0.0325(0.0761)$ \\
\hline & Occupational autonomy (poverty) & $0.000107(0.0390)$ & $0.0195(0.0419)$ & $-0.0518(0.0412)$ & $-0.0211(0.0565)$ & $2.431 * *(0.0437)$ & $2.603 * *(0.0549)$ & $0.0501(0.0456)$ & $-0.0272(0.0576)$ \\
\hline & Occupational autonomy (wealth) & $0.0411(0.0392)$ & $0.00970(0.0751)$ & $0.164 *(0.0664)$ & $0.221 *(0.103)$ & $-2.262^{* *}(0.0519)$ & $-2.488 * *(0.0805)$ & $-0.0379(0.0583)$ & $-0.215^{*}(0.0878)$ \\
\hline & Subjective health (poverty) & $-0.229 * *(0.0867)$ & $0.00721(0.0870)$ & $0.0951(0.0900)$ & $0.0628(0.0986)$ & $0.170+(0.103)$ & $-0.0543(0.118)$ & $2.275^{* *}(0.0719)$ & $2.229 * *(0.0701)$ \\
\hline & Subjective health (wealth) & $0.0711^{* *}(0.0234)$ & $0.0433(0.0276)$ & $-0.0184(0.0357)$ & $-0.0467(0.0391)$ & $-0.0141(0.0384)$ & $-0.124 * *(0.0462)$ & $-2.250 * *(0.0319)$ & $-2.306 * *(0.0352)$ \\
\hline \multirow{10}{*}{$\Delta \mathrm{t}-2$} & Life satisfaction & $-0.270^{* *}(0.00629)$ & $-0.259 * *(0.00658)$ & $0.0190 *(0.00769)$ & $0.00515(0.00816)$ & $0.0114(0.00871)$ & $0.0174+(0.0100)$ & $0.00954(0.00718)$ & $0.0163 *(0.00774)$ \\
\hline & Individual income (poverty) & $-0.0272(0.0476)$ & $0.0119(0.0306)$ & $0.847^{* *}(0.0554)$ & $0.912 * *(0.0363)$ & $0.0404(0.0653)$ & $-0.115 *(0.0492)$ & $0.0707(0.0591)$ & $-0.0450(0.0399)$ \\
\hline & Individual income (wealth) & $-0.0176(0.0258)$ & $-0.0107(0.0561)$ & $-0.977 * *(0.0354)$ & $-1.090^{* *}(0.0728)$ & $0.0902 *(0.0406)$ & $0.0364(0.113)$ & $-0.0101(0.0379)$ & $-0.00478(0.0793)$ \\
\hline & Occupational autonomy (poverty) & $0.0187(0.0353)$ & $0.0294(0.0390)$ & $-0.0320(0.0357)$ & $0.0338(0.0478)$ & $1.180 * *(0.0397)$ & $1.310 * *(0.0476)$ & $0.0396(0.0453)$ & $0.0310(0.0521)$ \\
\hline & Occupational autonomy (wealth) & $0.0129(0.0410)$ & $0.0182(0.0735)$ & $0.200^{* *}(0.0622)$ & $0.0442(0.0998)$ & $-1.052^{* *}(0.0540)$ & $-1.197^{* *}(0.0820)$ & $0.0773(0.0573)$ & $-0.204 *(0.0909)$ \\
\hline & Subjective health (poverty) & $-0.127(0.0938)$ & $0.0180(0.0914)$ & $0.177+(0.102)$ & $-0.156(0.0957)$ & $0.0974(0.111)$ & $-0.0727(0.0949)$ & $1.102 * *(0.0746)$ & $1.103 * *(0.0639)$ \\
\hline & Subjective health (wealth) & $0.0341(0.0223)$ & $0.00209(0.0260)$ & $0.0158(0.0316)$ & $-0.0814 *(0.0365)$ & $-0.0740 *(0.0368)$ & $-0.0411(0.0478)$ & $-1.134 * *(0.0267)$ & $-1.066 * *(0.0291)$ \\
\hline & Year effects & Yes & Yes & Yes & Yes & Yes & Yes & Yes & Yes \\
\hline & (Pseudo-)R $\mathrm{R}^{2}$ & 0.256 & 0.249 & 0.214 & 0.200 & 0.270 & 0.290 & 0.264 & 0.271 \\
\hline & Number of observations & 36.611 & 29.347 & 35.134 & 27.529 & 34.909 & 27.344 & 36.618 & 29.344 \\
\hline
\end{tabular}

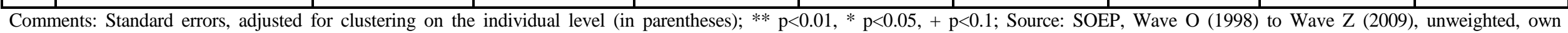
calculations. 


\section{6) Conclusion}

The aim of this study was twofold: (1) To answer the question which role endogeneity plays in wellbeing research. (2) To depict the interaction between poverty, wealth and life satisfaction overall and especially for men and women. The empirical analyses rely on data taken from the SOEP questionnaire (1998-2009). Based on the applied method (reduced form vector autoregressions) one can suppose granger-causality. However, this comprehension of causality needs to be strongly separated from causality in a common sense.

It was demonstrated that a rise in life satisfaction can improve individual income as well as subjective health. This principally supports the results of Binder and Coad $(2010 ; 2011)$ and also of Graham et al. (2004). Especially the latter effect is very robust against the model specification.

Moreover, the influence of an initial gain in life satisfaction on the occupational autonomy strongly depends on the applied model. Primarily on the level of sub-groups this effect should be doubted and was observed predominantly for women.

Furthermore, the impact of an increased satisfaction on subjective health is very robust for women. Additionally, the effect of a gained satisfaction on individual income can be seen as robust. Again, this underpins the insights of Binder and Coad (2010; 2011).

Moreover, an enhanced satisfaction raises the probability to return from unemployment to employment for men. This impact should be doubted for women. That result is in contrast to the findings of Binder and Coad (2010), who only observed this effect for women. These discrepancies might be explained by the different sample and also by the different definitions of the variables for well-being and employment status. In addition, the negative autocorrelation within the framework of life satisfaction (and the other regressands) can be interpreted as an evidence for adaptation-effects, because further positive changes are less probable (cf. Binder \& Coad, 2010, p. 360).

To recap, I found that an initial increase in life satisfaction has a sustainable influence on subjective health, employment status and the individual income. Thus, the assumption that the value of life satisfaction measures is short-term by nature should be reconsidered.

Future studies should apply the methodical approach in other national (like PASS data) or international panel data sets (e. g. HILDA or RLMS) to validate these findings. Regarding the income, a separation between industries and labour status (lifetime officials vs. self-employed person) seems promising. Probably, large differences in the effect of an improved satisfaction on individual income could be observed due to the different determinants of individual income (e. g. job tenure, wage group). 


\section{References}

Becchetti, L., Pelloni, A. \& Rossetti, F. (2008). Relational goods, sociability, and happiness. Kyklos, $61(3), 343-363$.

Binder, M. \& Coad, A. (2010). An examination of the dynamics of well-being and life events using vector autoregressions. Journal of Economic Behavior \& Organization, 76 (2), 352-371.

Binder, M. \& Coad, A. (2011). Disentangling the circularity in Sen's Capability Approach: An analysis of the co-evolution of functioning achievement and resources. Social Indicators Research, 103 (3), 327-355.

Binder, M. \& Ward, F. (2011). The structure of happiness: A vector autoregressive approach (Papers on Economics and Evolution, Nr. 1108). Jena: Max-Planck-Institut für Ökonomik.

Bottan, N. C. \& Truglia, R. P. (2011). Deconstructing the hedonic treadmill: Is happiness autoregressive? Journal of Socio-Economics, 40 (3), 224-236.

Easterlin, R. A. (2003). Explaining happiness. Proceedings of the National Academy of Sciences, 100 (19), 11176-11183.

Gardner, J. \& Oswald, A. J. (2007). Money and mental wellbeing: A longitudinal study of mediumsized lottery wins. Journal of Health Economics, 26 (1), 49-60.

Graham, C., Eggers, A. \& Sukhtankar, S. (2004). Does happiness pay? An exploration based on panel data from Russia. Journal of Economic Behavior \& Organization, 55 (3), 319-342.

Hajek, A. (2013). Der Einfluss von Armut und Reichtum auf die Lebenszufriedenheit. Eine empirische Analyse mit dem SOEP unter besonderer Berücksichtigung des Capability Approach. München: Herbert Utz Verlag.

Hoffmeyer-Zlotnik, J. H. P. \& Geis, A. J. (2003). Berufsklassifikation und Messung des beruflichen Status/Prestige. ZUMA-Nachrichten, 27 (52), 125-138.

Kassenboehmer, S. C. \& Haisken-DeNew, J. (2009). You're fired! The causal negative effect of unemployment on life satisfaction. Economic Journal. 119 (536), 448-462.

Schimmack, U. (2009). Well-being: Measuring wellbeing in the SOEP. Schmollers Jahrbuch Zeitschrift für Wirtschafts- und Sozialwissenschaften, 129 (3), 1-9.

Wagner, G. G., Frick, J. R. \& Schupp, J. (2007). The German Socio-Economic Panel Study (SOEP) Scope, Evolution and Enhancements. Schmollers Jahrbuch 127 (1), 139-169.

Stock, J. H. \& Watson, M. (2001). Vector autoregressions. Journal of Economic Perspectives, 15 (4), 101-115. 